Discussions about indigenous, national and transnational Islam in Russia

\title{
Aitamurto, Kaarina
}

2019-03-15

Aitamurto , K 2019 , ' Discussions about indigenous, national and transnational Islam in

Russia ' , Religion, State and Society , vol. 47 , no. 2 , pp. 198-213 . https://doi.org/10.1080/09637494.2019.1582933

http://hdl.handle.net/10138/308561

https://doi.org/10.1080/09637494.2019.1582933

unspecified

acceptedVersion

Downloaded from Helda, University of Helsinki institutional repository.

This is an electronic reprint of the original article.

This reprint may differ from the original in pagination and typographic detail.

Please cite the original version. 
Discussions about indigenous, national and transnational Islam in Russia

RELIGION, STATE \& SOCIETY

https://doi.org/10.1080/09637494.2019.1582933

Kaarina Aitamurto

\section{ABSTRACT}

Transnational Islam is increasingly presented in the Russian political rhetoric as a security threat. Therefore, Russian politicians and authorities attempt to support indigenous or national forms of Islam. Similar policies are implemented in several western European countries. Yet they tend to disregard the heterogeneity of the Muslim community, they create exclusions and they are often conceived as imposing outside evaluations and interpretations on Islam. This contribution analyses initiatives intended to develop a national Islam in postSoviet Russia. While the aims, methods and problems in different countries are often quite similar, the values and norms underlying these initiatives vary and reflect the societies from which they emerge. This contribution argues that since the 1990s, the changes in the political line of the Kremlin have impacted the project for a 'national' Islam by placing less emphasis on liberal values and more emphasis on adherence to loyalism and political conservatism.

\section{Introduction}

In 2013, in a meeting with leading Russian muftis, President Putin (2013) stated that One of the most important tasks [is] recreation of our own Islamic theological school, which will guarantee the sovereignty of the Russian spiritual sphere and, which its primary importance, will be acknowledged by the majority of Muslim scholars of the world. Putin's wish to create a national Islam in Russia is not unique. In recent decades, many European political leaders have entertained similar aspirations (Laurence 2006, 255-258). The reasoning behind this political aim is that a national Islam supposedly promotes liberal forms of Islam, strengthens Muslim loyalty to the country where they live and, conversely, weakens the importance of transnational ties and the appeal of radical propaganda from abroad.

The aim to create 'national Islams' is actively promoted and supported with different policies by many states, including Russia. However, several scholars have noted that attempts to formulate a national Islam regularly face difficulties because they tend to disregard the diversity of the Muslim communities and thus end up creating hierarchies and exclusions (Sunier 2014; Braginskaya 2012; Sakaranaho 2015). The globalisation and transnational nature of religions, including Islam, pose challenges to the idea of 'de-transnationalisation'. This contribution examines the initiatives aiming to develop Islam in Russia, that is to definewhat it 
is and what it should be. The cases have been selected to reflect both the changes in how a 'good' Islam is conceived in Russia from the 1990s to 2010s and to provide examples of the challenges they encounter. I use primary material from these programmes and the public discussions they evoked as well as previous studies on this topic. This analysis highlights that the reasons why the different formulations of Russian Islam have failed to gain the support of the majority of Muslims in Russia are very similar to those pointed out in previous studies in the European contexts. Despite the similarities in policy aims, methods and outcomes, the historical, cultural, societal and political context has a significant impact on the conceptualisations of an ideal national Islam. My hypothesis is that Russia's turn towards authoritarianism in the 2000s and the conservative and even anti-western turn in the 2010s have a considerable impact on the Russian debates of what constitutes a 'good Islam' in the process of creating a national, 'Russian Islam'.

\section{The governance and domestication of Islam}

The concern that transnational religious identities may jeopardise the loyalty of citizens to the state is by no means a new phenomenon. Neither are the political programmes designed to manage these loyalties. Furthermore, Muslims have not been the only 'suspects'; for example, throughout the modern history of Europe, Jews, Catholics in Protestant countries, and Protestants in Catholic areas have faced similar distrust and even persecution (Laurence 2006, 257). As in western Europe, suspicions over the true loyalties of the Muslim population are not a new phenomenon in Russia. The Tsarist regime already had concerns over pan-Islamism and pan-Turkism among its Muslim subjects (Crews 2009, 296-308). In the Soviet times, several religious minorities faced persecution based on their allegedly foreign allegiances.

In western Europe, contemporary discussions on the need to support local Islam sprung out of fears over the isolationism and radicalisation of the Muslim community in the 1980s, which intensified in the 1990s. At the same time, Russia was immersed in enjoying the opening of its borders, but also in experiencing tremendous economic and social problems. Amidst the climate of depression, the Russian state had limited means to support the revival of Islamic religious buildings and schools that had suffered severely during the Soviet regime. For example, the majority of mosques had been demolished or converted into buildings that were used for other purposes, such as warehouses. Therefore, the state had few objections to foreign funding for Muslim communities in Russia. Financial assistance, as well as ideas and information, flooded into Russia originating in myriad sources with both their own Islamic traditions and motives, ranging from countries such as Saudi Arabia, Turkey, as well as from rich Islamic foundations and international organisations, such as Hizb ut-Tahrir, and propagators of militant Islam.

A shift in the state's and public attitudes towards foreign Islamic influences took place with the nationalist turn in the second part of the 1990s, but especially during the Chechen wars. When the media representations of the conflict became more religiously coloured by the political rhetoric of each side of the conflict, and after some foreign Muslims volunteers joined the war (Radnitz 2006), public attitudes towards Islam, especially towards transnational Islamic networks, became more negative. After 9/11, the urge to 'moderate' Islam became one of the top political priorities globally and many governments attempted to develop a proactive mode in the governance of Islam. In Russia, as in western Europe, transnational Islam was often seen as one of the main 
threats to national cohesion and security (Yazbeck Haddad and Golson 2007, 488-9). Two main worries over transnational Islam were the spread of radicalism from abroad and undermining the loyalty of the local Muslim population to their home country.

In countries with indigenous Muslim populations, such as Russia, the concern over foreign radical influences often translates into discussions about the 'Arabisation' of local Islam. A prevailing feature of these discussions is the juxtaposition of the tradition of 'our' moderate Islam and the corrupting, uncompromising, Islam of Arabic countries (Rexhepi 2018). However, several studies have questioned these assumptions by demonstrating that militant ideology may also draw local Islamic traditions. For example, in his study of Russian language jihadism, Danil Garaev (2017) notes that its appeal lies not so much in jihadism's international rhetoric and ideas, but its creative use of Russian and Soviet intellectual tradition. While Salafism is often attributed to foreign radicalism in Russia, Alfrid Bustanov demonstrates how Tatar activists subscribe to Salafism while at the same time referring to local Tatar traditions in order to claim legitimacy of their version of the religion. (Bustanov 2017).

For the Muslim communities, the securitisation of Islam and suspicion over its nature as a transnational religion and community lead to a constant need to prove their loyalty to the state. Solidarity within the global ummah may become suspect, especially when it engages with political aspects. The underlying assumption is that Muslim solidarity and loyalty to one's country are exclusive (Ajala 2014, 123-127). While such prejudiced views are often contested by local Muslims, John R. Bowen $(2004,44)$ argues that as a part of their rhetorical resources at least, many Muslim actors have concurred with the idea of a national Islam as a goal worth pursuing.

The pressure towards the 'domestication' of Islam is part and parcel of the contemporary securitisation of Islam. Both ideas create exclusionary hierarchies by labelling some forms of Islam as harmful. Jocelyn Cesari $(2012,436)$ notes that the mere fact that in today's Europe the 'good' Muslims must be separated from the 'bad' ones reveals an 'underlying assumption that Islam is a potential menace to society.'

A key idea in the construction of a 'good' Islam in Russia is the term 'traditional Islam'. This expression usually refers to the form of Islam that is loyal to the state, secularised and draws to local traditions. Local traditions may refer, for example, to ethnic heritage, Russian intellectual traditions or even indigenous Islamic schools of jurisprudence. The apparent vagueness and political nature of the term 'traditional Islam' have raised criticism from Russian scholars of Islam and within the Muslim community itself (Alekseev 2004; Dudoignon 2015). In public, including political, discussions, the division between 'traditional' and 'non-traditional' or 'political' Islam has served as a convenient rhetorical means to defend the suppression of non-compliant activities and organisations, and to avoid accusations of Islamophobia (Rogozina 2018). These terms are also used by Islamic leaders to marginalise their competitors by accusing them of not representing the "true tradition of Islam' or of representing politicised, aggressive or intolerant views (Alexeev and Rogozina 2017). However, as Matteo Benussi (2018) notes, the diversification of Muslim communities challenges the authority of muftiates, and Muslim leaders increasingly face pressures to abandon such normative and exclusionist concepts as 'traditional Islam', especially as they are difficult to integrate in the context of Islamic tradition.

The definitions of 'good' Islam reflect the values and norms of the surrounding society so they also adapt to societal changes. Since the beginning of the 1990s, 
Russian society has consistently moved towards a more nationalist and conservative direction. The change began as a reaction to the social turmoil of the 1990s, which came to be associated with liberal policies of the time. Calls for social stability and order, and for the restoration of the national pride became more vociferous. A consistent feature of Putin's regime has been growing authoritarianism, which also guides policies pertaining to religion and belief. The vaguely worded law against extremism (Law No. 114-FZ), introduced in 2002, gives the authorities much more room for manoeuvre and has been widely used against minority religions and unsanctioned religious activity. On the basis of this Law, numerous Islamic organisations have been forced to close and thousands of Islamic publications banned, some on very questionable grounds (Fagan 2013, 158-161; Verkhovsky 2018, 17-18). This authoritarianism has also hindered expressions of dissent and strengthened the pressure to conformity. Therefore, Russian Islamic communities feel increasing pressure to prove their loyalty to the state and to refrain from any controversial actions.

While in the 1990s, the ideas of liberalism, modernisation and pro-Europeanism were highly esteemed, in the 2000s, and especially in the 2010s conservative values and antiwesternism came to be valorised. In its foreign policy, the Russian government began to advocate the idea of a multipolar world and sought to make new alliances, especially with Asian countries, including those with Muslim majorities. Unlike in western Europe, Muslims in Russia have a long history and are an officially acknowledged historical minority. Yet, at the same time, the Kremlin has flirted with ethno-nationalist antiMuslim nationalist sentiments. After the strengthening of the nationalist opposition, Putin's administration has adopted some of its themes (Tolz and Harding 2015; Arnold and Markowitz 2018, 1561). In recent years, Russia's political elite, and several local level authorities and courts have taken a negative stance towards issues such as the right to wear a hijab in schools (Laruelle and Yudina 2018, 56-59). Proposals to build new mosques are increasingly rejected by the authorities (Aitamurto 2016). At the same time, the power of the Russian Orthodox Church (ROC) has strengthened and it has greater influence on the policy decisions concerning religion, both locally and nationally. Unsurprisingly, the ROC prefers those Islamic organisations1 which it sees as most compliant to its own interests because they appear more willing to accept its hegemonic position in Russia (Curanovic 2010).

Muslim reactions to political pressure by the state to limit their contacts with foreign Islamic entities vary. Many Russian Islamic leaders agree that Russian Muslims should focus on reviving and studying their own tradition instead of looking abroad. However, they also aim to demonstrate the benevolent aspects of international cooperation. One way of doing this is to refer to the diplomatic support that the Russian Muslim community and leaders may provide to the Russian state. For example, there are financial opportunities for Russian entrepreneurs in international markets, including the annual Halal Expo in Moscow. Another strategy is having Muslim leaders in Russia make statements that Islam is the same everywhere and that its malevolent, radical forms, are not a part of 'true' Islam. Although this rhetoric aims to challenge the assumption that foreign influences are an intrinsically worrisome phenomenon, it reproduces the dichotomy of 'good' and 'bad' Islam.

Normative language on the perils of foreign influences imposes restrictions on Islamic organisations, but it can also be used towards their advantage. For example, by referring to the assumed threat of radicalisation of imams who study abroad, Islamic actors in 
Russia may request state support for the development of domestic Islamic educational institutions. Representing oneself as a champion of the Russian native tradition and Islamic education can be rewarded by the state in various ways, but it may also serve as a rhetorical weapon in rivalries with other Islamic actors. An example of such internal divisions are the debates about hiring foreign teachers in a new Bulgarian Islamic Academy in 2017. Among the various accusations made, were charges on jeopardising the 'sovereignty' of Tatar and Russian Islam by handing down the control of the development of Russian Islam to foreign actors (Gibadullin 2018).

\section{Policies promoting the 'domestication' of Islam}

The policy aim of nationalising Islam can be discerned not only in Russia, but in virtually most European countries. Despite the differences in histories, demographics, cultures and politics, some shared features can be noted. Providing benefits to a 'statesanctioned' Islam is a crucial tool in the proactive governance of Islam. Since the 1990s, and in the 2000s especially, several European governments have begun to allocate funding to domestic Islamic organisations. Domestic funding of mosques and local imam training are seen as an effective means to prevent the influence of foreign countries on the Muslim minorities through religion (Yazbeck Haddad and Golson 2007, 499-509; Elbasani and Tošić 2017, 502).

In a similar vein, in order to curb foreign influences on Russian Islam, the Russian government has also created different kinds of incentives. Although according to its Constitution, the Russian Federation does not provide funding to religious organisations, it does so indirectly. In 2007, the Fund for Support of Islamic Culture, Science and Education (FSICSE) was established, which receives generous funding from the state and companies controlled by the state. The allocation of funds to Russian Islamic activities promotes the strengthening of domestic education, publishing and other forms of cultural activities. At the same time, it is a vital replacement to the funding from abroad that Islamic organisations previously received.

The training of imams abroad is a topic which frequently emerges in discussions about the spread of radicalism. Experts, who are known for their alarmist comments regarding the spread of radical Islam, are especially active in these discussions. For example, Roman Silant'ev, former executive secretary of the Interreligious Council of Russia and member of the Moscow Patriarchate's Department for External Church Relations, suggested in 2015 that imams who have studied abroad should not be allowed to preach in Russian mosques (Pumma 2015). The largest Russian muftiates (Islamic authorities) seldom disagree that religious education abroad entails the risk of radicalisation of their students. In addition, they agree that foreign Russian imams may adopt Islamic traditions that are more conservative and rigid than those prevalent in Russia and that foreign training does not prepare imams to help Russian Muslims to face the challenges of everyday life in Russian society. However, practical reasons prevent the imposition of any heavy sanctions for Russian imams going to study abroad. Although there are Islamic higher education institutes in Russia, they naturally are not at the same level as the most established ones abroad. Fluent Arabic is also challenging to master without spending some time in countries where it is the native language. Russian Islamic leaders are aware that the authority of imams with a lower level of Islamic education can be easily undermined or challenged by 'unofficial' religious leaders who have expanded their knowledge of Islamic tradition 
and Arabic language abroad.

In many European countries, authorities encourage the use of the national language in sermons instead of Arabic or other foreign languages. Similarly, in Russia, the language issue is connected to the securitisation of Islam. Yet, the case of Russian Islam demonstrates the difficulties in defining what is national, even in terms of language, and drawing the boundaries around traditions that require protection from outside influences. For speeches intended for the general public, muftis may prefer Russian, using expressions of Christian origin instead of established Arabic terminology, in order to create the image of a domestic Islam with a close affinity to Orthodox Christianity (Kemper 2012; see also Sibgatullina 2019, in this special collection). However, the use of Russian instead of minority languages, such as Tatar, is occasionally viewed as entailing a risk of radicalisation. For instance, in 2016, the Muslim Religious Board of the Republic of Tatarstan (MRBRT), ordered that Friday sermons in the mosques in the Republic must be conducted in the Tatar language. The Tatar muftiate justified the decision on grounds that it would contribute to preservation of the Tatar language and culture. However, statements by some leading figures in the muftiate reveals their views on the connection between the use of the Russian language and radicalisation. 2 For example, while explaining the decision, Rustam Batyr, first deputy of the mufti at the time, recounts the story of an imam who delivered sermons in Russian in a mosque in Tatarstan. According to Batyr, many people visiting this mosque had become radicalised. Though this imam had not propagated any radical ideas, Batyr argues that his teachings led to the radicalisation of the members of this mosque because by using Russian, his sermons and the teaching of Islam was not referring to the 'native culture, Tatar land, our Fatherland.' According to Batyr, the issue boils down to whether one subscribes to globalism or anti-globalism. He argues that Islam is always national and not accepting this national nature amounts to Wahabism (Batyr 2016).

A common approach to the governance of Islam in Europe is the authorities' aim to seek trusted interlocutors from the Muslim community (Yazbeck Haddad and Golson 2007). Islamic actors engaged in this type of cooperation with the state receive material and other benefits, which function as incentives for Islamic organisations to accommodate their activities to the expectations of the state. For example, as a part of the cooperation, several European states have issued founding documents for different kinds of technical working groups and representative councils in which the Islamic organisations commit themselves to respecting the laws of the state (Laurence 2006, 271). In Russia, President Putin meets the leading muftis on a regular basis and they are invited to many state-sponsored events, such as those in the Civic Chamber, a consultative body monitoring activities of the government and legislature. Collaboration with the authorities at a local level also provides opportunities for Islamic organisations to get their voice heard and to influence local decision-making.

\section{How do the policies work?}

The proactive policies to shape Muslim communities by selective invitations to cooperation have occasionally backfired. Initiatives imposed from above to nationalise Islam often rely on traditional views of religious authority. Yet, Islam is also affected by the individualisation and diversification of religiosity in the modern world. As in contemporary Christianity, as a lived religion in Europe, traditional authority has eroded in Islam. Olivier Roy points out that Muslims, especially younger generations, increasingly consider 
it their right to look for religious knowledge independently (Roy 2006, 158-171).

For example, children of Muslim migrants may criticise their parents' ethnically coloured religious traditions and practices, in favour of seeking more 'authentic' forms of Islam from the Internet and international global networks. Initiatives to develop local or national forms of Islam that are adapted to a western context may also emerge beyond established organisations. For example, in his study of Australian Muslim communities, Hadi Sohrabi (2016) encountered young Muslims who were frustrated by the shortcomings in the English language proficiency and knowledge of local customs of many imams, thus seeking to create forms of Islam that were better adapted to Australian society. Indeed, Abdullah Saeed argues that 'efforts at nationalising or secularising Islam have had a negative impact on the emergence of a fully western form of Islam. A western form of Islam must come from within the Muslim community rather than be imposed by national governments' involvement' (Saeed 2009, 203). An eminent Russian scholar of Islam, Stanislav Prozorov (2004, 377), reached a similar conclusion and emphasised both the gradual evolution of local forms of Islam and the difficulties of imposing normative forms from above.

The conceptualisation of an Islamic national or local tradition, can reinforce an essentialist understanding of religiosity. The idea that there is some authentic, pure form of religiosity, for example a 'Russian traditional Islam', that can be recovered as it was and be shaped as it should be, is simplistic and disregards the continuous development and heterogeneity of religiosity. In reality religious traditions are always interpreted and constructed from a pool of elements. For example, in recent years the right to wear a hijab in schools have been debated in Russian society and among Russian Muslims. In these debates, the 'tradition' features as a value that is commonly referred to, but with great variations in how it is understood and practised. We can identify two main ways in which the idea of 'our national tradition' is referred to in debates on the right to wear a hijab in school: the notion of Russia as the ideal model for interfaith harmony and the idea of headscarves as part of the Russian Orthodox tradition. An example of the former is Mufti Nafigulla Ashirov, who in his defence of Muslim pupils' right to wear a hijab in school, refers to President Putin's words on 'spiritual unity', based on the dialogue between 'traditional' religions as an integral part of the uniqueness (samobytnost') of Russia, and the idea of Islam as an inseparable part of Russian 'cultural code' (Ashirov 2017). An example of the latter is Mufti Ravil' Gainutdin's argument that modest dress, including wearing a headscarf, is a Russian tradition that was also followed by both Orthodox Christians and Jews (Gainutdin 2015).3 Some Islamic leaders do not categorically oppose the banning of the hijab in public schools, referring to the Russian Islamic tradition. For example, Damir Mukhetdinov, Deputy Chairman of the Board of Muslims of the Russian Federation, does not see wearing the hijab as a requirement for contemporary Muslim women (Mukhetdinov 2017). His main argument is the need to adapt to modern society. Yet, he also finds justifications for voluntarily wearing the hijab in the work of Musa Bigiev, an authoritative Tatar theologian.

The designation of desirable Islamic organisations as partners and the accompanied benefits of collaboration with the state create both exclusions and inclusions, often causing internal disputes. Since the post-Soviet religious revival, in the 1990s, there has been increased rivalry between numerous competing Russian Muslim organisations. It can be argued that the discord is further fuelled by the competition between such organisations over who will achieve a privileged status and position as a partner of the state and the corresponding authority to define the Russian Islamic tradition. The 
attempts of Islamic organisations and actors in Russia to create a national Islam also often provoke criticism among Muslims, especially if these attempts are viewed as imposed by the state or designed to please the authorities. A common accusation is that in such cooperation Islamic organisations are co-opted by the state to promote its own interests and thus compelled to exclude certain Muslim communities (Loobuyck, Debeer and Meier 2013; see also Yazbeck Haddad and Golson 2007).

\section{Initiatives to create a national Islam of Russia}

There is broad political consensus on the need to support some kind of Russian Islam (Rossiiskii Islam), 4 but also various discussions about the local religious specificities within the Muslim communities. An analysis of discourses on this topic in areas with different histories, religious traditions and political environments such as Tatarstan, Dagestan or Chechnya, is a topic in itself, beyond the scope of this contribution. The focus here is on nationwide discussions and initiatives to develop specific domestic configurations of Islam in Russia, which illustrate the tensions between the political aspirations of the Russian state and the Muslim communities, and the challenges in formulating an 'Islam in Russia' that would be espoused by the whole Muslim community of Russia.

Tatars form the biggest ethnic group (around 5,000,000) among Russian Muslims and Tatarstan has a long history of being a part of Russia. It is widely accepted that Tatar Islam is a less troublesome, moderate and loyal religion than Islam in the Northern Caucasus, where religion played a crucial role in the opposition to the bloody conquest of the area to the Russian empire in the eighteenth and nineteenth centuries. Although different areas have their own traditions, the Russian state seems to look more favourably on Tatar Islam and the Hanafi madhab (school of thought) as a model case (Braginskaya 2012, 610). Not surprisingly then, Tatar Islamic leaders have often benefitted from a leading role in the discussions about what Islam in Russia should be like.

\section{Rafael Khakimov's Euro-Islam}

In the 1990s, Rafael' Khakimov, who at the time worked as an adviser to the President of Tatarstan, began to formulate a modernist, reformist and secularised version of Euro-Islam, 5 the central tents of which he elaborated in his Gde nasha Mekka? (Manifest Evroislama) [Where is ourMecca? A Manifesto of Euro-Islam] in 2003. Khakimov's Euro-Islamis based on individual freedom and adapting religion to modern society. Khakimov sees madhhabs as obsolete and an obstacle to the development of Islam into a progressive form; he also downplays the importance of religious observance. Khakimov's thinking reflects an occasionally somewhat uncritical admiration of the West reminiscent of the early 1990s. For Khakimov, the West is a model from which Islam should learn and to which Russian Muslims should turn to.

According to Khakimov, the growing interest of Tatar youth to learn English instead of Arabic is a welcomed trend because: 'Arabic brings into our society a backward mentality, but western European languages help us break new boundaries.' (Khakimov 2007, 299). Although Khakimov's manifesto inspired some Islamic intellectuals and politicians in the Republic, it also caused criticism within and outside Tatarstan's borders by the wider Muslim community in Russia. They accused Khakimov's manifesto of disparaging some fundamental elements of Islam or Sunnism, and making Protestant Christianity a model towards which the 'backward' Islamic world should strive (Khurmatullin 2010, 113-115). 
In 2013, Khakimov published an online article entitled 'Gde nasha Mekka - Versiya 2.0'

[Where Is Our Mecca - Version 2.0'] in which he rejected what he saw as the clericalisation of Russian Islam and criticised the Islamic leaders for having abandoned the reformist tradition of both Tatar Islam and the founder of Hanafism, Abū Hanīfa (Khakimov 2013). This second manifesto received even harsher criticism than Khakimov's first book, undoubtedly because of his attack on the Russian Islamic establishment, but also because in ten years his secularist and pro-western interpretation of Islam has become even more marginal.

\section{Conservatism and Tatar Islam}

Though Khakimov's Euro-Islam did not attract much support among Russian Muslims, many other Russian and Tatar religious and secular leaders have sought to position themselves as avant-garde and exemplar thinkers of moderate and modern Islam in the European context. However, the ideals of a Russian or Tatar Islam are also subject to wider societal and political changes. Indeed, the shift in the societal values and political line of the Russian Federation towards conservatism and anti-westernism can also be noticed in the thinking of Tatar theologians. Revealingly, while Khakimov and many Russian Islamic leaders claim Jadidism to be one of the cornerstones of Russian Islam, an increasing number of theologians and muftis, including, for example, Kamil' Samigullin, the current mufti of the MRBRT, tend to adhere to the historical Tatar Islamic tradition of Qadidmism (di Puppo and Schmoller 2018). These two traditions have customarily been juxtaposed as representatives of liberalism and reformism (Jadidism) and conservatism (Qadidism). Several recent studies have criticised this simplistic representation and demonstrated that the image of progressive Jadidism was mostly created in Soviet times to construct a model of Islam that suited the values of the political establishment (Bustanov and Dorodnykh 2017; DeWeese 2016). However, these views remain deeprooted which is illustrated in the debates among Islamic scholars and secular academics. In a similar way, as 'progressive' Jadidism was favoured in Soviet times, it might be argued that the conservative turn in Russian society has made 'conservative' Quadidism more societally acceptable than it was in the 1990s.

Like many other Tatar Muslim leaders, mufti Samigullin suggests that Europe could learn interreligious tolerance from Tatarstan. Yet, he is a stout opponent of the kind of reformism that would include making concessions to secularism. According to Samigullin, the Hanafi tradition, which the MRBRT subscribes to, 'is in some sense the most conservative' of the madhhabs (Afanas'ev 2013). It should be noted that the wide support of conservatism by contemporary Russian Islamic leaders does not necessarily mean unanimity in their theological and societal views. Endorsement of political and societal conservatism does not necessarily entail commitment to theological antireformism. For example, Damir Mukhetdinov, First Deputy Chairman of the Spiritual Board of Muslims of Russian Federation, also subscribes to conservative values and argues for a community that would unite Russian Muslims on the basis of 'antiglobalism, defence of traditional values, traditional multiculturalism and moderate conservatism' (Mukhetdinov 2016, 6-7). Despite his harsh criticism of liberalism and in particular 'ultra-liberalism', Mukhetdinov and his theological views have been accused of being secularist, for example, after he argued that wearing hijab is not a religious prerequisite. He has also been criticised of being too lenient with reformist and secularist forms of Islam (Muftii SMR, 2017). 
The Russian muftiates have drafted various documents designed to formulate shared values and common rules. For example, the Social Doctrine of Russian Muslims ("Sotsial'naya doktrina rossiiskikh musul'man" 2015), written by a working group, headed by Ali Vyacheslav Polosin, vice director of the FSICSE, was signed in Tatarstan in 2015. The document resembles the Foundations of the Social Concept of the Russian Orthodox Church, published in 2001; it showcases the Muslim community as an equivalent pillar of Russian society and a loyal partner of the state. Indeed, the document even includes an excerpt from Putin's statement from 2013 on the need to develop Russian Islam, as quoted in the beginning of this contribution.

The document can also be read as a response to political pressures about Islam. To appeal to the ROC, the document argues that attempting to proselytise Islam among Jews and Christians is against the Quran. In response to concerns over the influence of foreign countries, it states that Russian students of Islam should complete their primary studies in Russia and that higher education studies abroad should be organised exclusively by the official muftiates in Russia. In political terms, the document adheres faithfully to Putin's antiwestern and conservative rhetoric. Similarly to the ROC (see Stoeckl 2016), the document criticises western notions of universal human rights as overlooking traditional values: The elaboration of declarations and legislature on the human rights by Europeans from seventeenth to nineteenth century attest of the attempts of human spirit to free itself from the ignorance toward truth. However, belittling of conservative and religious values in these acts has ultimately led to such extremes of modern liberalism as the public legitimization of vices, including the substitution of the historically formed concept of the family by the concept of same-sex marriage (Sotsial'naya doktrina rossiiskikh musul'man, 2015). The document claims that the Quran proscribes globalisation as a unification of nations, offering instead a vision for the 'preservation of ethnocultural and moral traditions' as one of the cornerstones of interconfessional harmony in Russia.

The document was signed mostly by the largest muftiates, except for the one in Chechnya. However, it has remained mostly theoretical without many practical outcomes, partly because undoubtedly it had very little to say about the everyday life and challenges of ordinary Muslims and contained few original theological insights. In reading the document, one might wonder whether it was targeted at Russian Muslims or at the political establishment as a declaration of loyalty and conformism. Repeating and adhering to the political line of the Kremlin would have excluded Muslims who might identify more with the political opposition.

\section{The Grozny Fatwa}

Another attempt to create a national form of Islam, without mentioning the idea of a 'Russian Islam' but motivated by a wish to strengthen one's position in the Russian Islamic scene, was the organisation of an international conference entitled 'Who Are They - the Followers of Sunna' (Kto oni - posledovateli Sunny Akhlo-sSunna va l'-dzhama 'a), in Grozny in August 2016.6 The conference was hosted by Salakh Mezhiev, Mufti of Chechnya, but it was widely assumed to have been initiated by Ramzan Kadyrov, President of the Chechen Republic. The aims of the conference included the development of an initiative to create a new all-Russian council of Islamic scholars (ulema) and the drafting of the document Grozny Fatwa (Groznenskaya fetva), which was to be 
presented as binding on all Muslims in Russia. The latter provoked much criticism among Russian Muslims mainly because the document presented Sufism as one of the requirements of true Sunnism; it also excluded several forms of Islam as heretical sects, including 'Wahhabism' and 'Salafism'. In addition, it was written by a limited number of Islamic clerics in the name of and for the entire Muslim community in Russia. Neither representatives of the Central Spiritual Board of Muslims in Russia nor Muftiates of Dagestan and Ingushetia attended the conference. The representatives of the Council of Muftis of Russia (CMR) left the conference early and the organisation did not sign the Fatwa (Tuaev 2016).

We can identify several reasons for the Chechen muftiate's failure to gather support by most of the main muftiates and largest umbrella organisations. First, other Islamic leaders were not ready to hand over the leading role of defining a 'true' Islam in Russia to the Chechen muftiate and Ramzan Kadyrov. Second, many were concerned that the Fatwa, which was targeted at Russian audiences, would be noticed abroad and that the exclusion of Wahhabi and Salafi Muslims, among others, would undermine the credibility of the signers in the eyes of the global Muslim community. The third reason was the apparent discrepancy between the heterogeneous Muslim scene in Russia and the rigidity and narrowness of the formulations of the Fatwa. Indeed, many Islamic leaders who criticised the Fatwa argued that it could create new tensions and divisions among Russian Muslims and alienate many Muslims from the muftiates, thus encouraging them to operate outside the institutional structures of 'official Islam'.

It is evident that the conference targeted not only the Russian Muslim community, but also the political elite and the authorities. After the conference, its organisers also sent an appeal that urged President Putin, the Russian government and the Federal Assembly to ban Salafism in Russia. This direct appeal and the conference's connection to President Kadyrov were undoubtedly important reasons why so many Islamic leaders refrained from slamming the Grozny Fatwa too bluntly. For example, the CMR used very diplomatic language in its refusal to sign the document. In its response, the CMR did not directly defend Salafism or Wahhabism and it even made a reference to Putin's statement on the importance of creating a national Islam. According to the response, it is vital to revive the 'centuries old, glorious Russian Islamic theological tradition' (Gainutdin 2016). However, the sentence continued by emphasising the diversity of regional theological Islamic schools, thereby undermining the idea of a single Russian Islam.

\section{Conclusions}

Supporting a national, 'domesticated' form of Islam is seen as a remedy against radicalisation, ghettoisation and divided loyalties, not only in Russia, but also in many European countries. Thus, Muslim communities feel both political and social pressures to outline what this kind of 'national Islam' is or could be. In many respects, the idea of creating a coherent 'national Islam' is unrealistic. Thijl Sunier notes that 'Muslims in Europe' is a social construct over which constant negotiations and struggles are waged (Sunier 2014, 1141). The traditions of lived religion are complex and in constant flux. They are open to myriad of different interpretations. Debates on the right to wear the hijab show that reference to 'our' national or regional tradition can be used to defend opposing positions. Moreover, the primacy of religious norms, ethnic traditions and the secular state is continuously negotiated in these discussions. 
The political projects to create national or domestic forms of Islam frequently suffer from both the failures to grasp the heterogeneity of being Muslim in the contemporary world and the failures of nationalism to understand and govern transnational phenomena in a globalised world (Aitamurto and Gaidukov 2018). Such endeavours, whether instigated from outside or within Muslim communities can easily disregard the diverse ways of being a Muslim and practising Islam.

The initiatives discussed in this contribution illustrate the types of questions that often arise from the ideas and aspirations to create a 'national Islam'. Who has the right to speak for the community or to define it? These projects represent different methods of promoting the nationalisation of Islam. While Khakimov formulated what he considered an ideal direction for the development of Islam in Russia, the Grozny Fatwa had the more normative goal of imposing religious and legislative constraints on what type of Islam is to be allowed to exist in Russia.

When Russian Islamic leaders recreate the discourse on the dichotomy between 'our traditional Islam' and the problematic 'foreign Islam', they are engaging in othering Muslims and creating hierarchies, including racialised ones. The struggles over hegemonic positions to define a 'national Islam' nourish internal power struggles which contribute to divisions within Muslim communities and bear the risk of discrediting Islamic leaders. Participating in state-supported initiatives to create a 'national Islam' may undermine the credibility of Islamic organisations also because of the compromises it demands. Ekaterina Braginskaya $(2012,615)$ notes that the CMR's cooperation with the state creates an impression that the SMR [CMR] is less concerned with representing Muslim interests to the state and more with communicating the state's objectives to the Muslim communities. This leaves the council vulnerable to accusations from some unofficial Muslim organisations that rather than promoting Islam in Russia, it 'domesticates it' and thus isolates Russian Muslims from the rest of the world.

However, among Russian muftiates, the CMR has actually often adopted a relatively independent line and not always readily submitted to political pressures.

The 'domestication' of Islam, even when coming from below without state intervention, tends to respond to social and political expectations. For example, Muslim communities may wish to enhance the image of Islam by developing their own identity. However, the domestication of Islam may also be motivated by a broader wish to gain resources and recognition for the community or to avoid anticipated accusations (such as having an unpatriotic stance or being sympathetic to radicalism or terrorism), which might then entail the risk of losing legal or financial privileges. In any case, the initiatives to develop a 'national Islam' have to strike a balance between internal and external expectations, values and norms. In this way, they also reflect and are shaped by societal and political changes.

Nation-states create spaces where Islam is influenced by the state's policies as well as the ideals and discourses of the society (Williams 2011). Changes in the emphasis of the various initiatives to create 'Russian Islam' reflect the shifts in the Russian dominant political rhetoric, in particular from liberalism to conservatism and anti-extremist rhetoric. This change in emphasis is also one of the most striking differences between the discussions about 'our national Islam' in European countries and Russia. The Social Doctrine of Russian Muslims sought approval from the Russian political elite by labelling same-sex marriage as an extreme expression of western liberalism. In contrast, a more 
successful tactic in western Europe would undoubtedly be declarations of tolerance towards sexual and gender minorities.

\section{Notes}

1. For example, the ROC is more sympathetic towards the Central Spiritual Board of Muslims in Russia than towards the Council of Muftis of Russia.

2. Ethnic Russians who convert to Islam are regularly presented as particularly vulnerable to religious radicalisation in public discussions. Since the ROC also strongly objects to any proselytising by Islam among ethnic Russians, the decision of the MRBRT was widely seen as a concession.

3. The preference for using Russian terminology in order to create the feeling of unity with Orthodox Christians, noted by Kemper (2012), manifests itself, for example, in recommending the use of the word 'scarf' (platok) instead of hijab (khidzhab) 'so that it would not seem that something alien and secret is imposed on us from outside' (2017).

4. The word 'Rossiiskii refers to Russians as citizens while russkii means Russian ethnic identity. Therefore the term russkii islam is associated with the Islam of ethnic Russians converts.

5. The idea of 'Euro-Islam' has also been developed in western Europe by Muslim thinkers, who seem to seldom know Khakimov. The diversity of different conceptualisations of Euro-Islam or European Islam reveal the difficulty in demarcating Europe. See (Hashas 2018; Nielsen 2007). 6. The participants from abroad included scholars from Egypt, some of whom stated later that they were not participating in writing or signing of the Fatwa.

\section{References}

Afanas'ev, S. 2013. “Kamil' Samigullin, DUM RT: 'Preemnik li ya Ildusa Faizova - Sprosite u nego...'.'’Kamil Samigullin, MRBRT: 'Am I the successor of Idus Faizov - ask him...'.] BusinessGazeta, March 23. https://www.business-gazeta.ru/article/77279

Aitamurto, K. 2016. 'Protected and Controlled. Islam and 'Desecularisation from Above' in Russia." Europe-Asia Studies 68 (1): 182-202. doi:10.1080/09668136.2015.1119250.

Aitamurto, K., and A. Gaidukov. 2018. "The Diversification of the Muslim Community in St. Petersburg in the 2010s." Journal of Religion in Europe 11 (2-3): 222-247.

Ajala, I. 2014. "Muslims in France, and Great Britain: Issues of Securitization, Identities and Loyalties Post 9/11." Journal of Muslim Minority Affairs 34 (2): 123-133.

Doi:10.1080/13602004.2014.911583.

Alekseev, I. 2004. "V poiskakh'khoroshego islama'." [In search of a 'good Islam'.] Ab Imperio 3: 409-412.

Alekseev, I. 2017. 'Ot 'khoroshego' islama k 'pravil'nomu': Kategorii I kontsepty v yazyke sovremennoi Rossiiskoi analitiki i ideologii." [From 'good' Islam to 'right' one: the categories and concepts in the language of contemporary Russian anslytics and ideology.] Islamology 7(1): 88-105.

Alyautdinov, I. 2017. "Muftii Alyautdinov: Khidzhab i 'rabota' Satany po dukhovnoi dezorientatsii obshchestva." [Mufti Alyautdinov: hijab and the 'work' of Satan in spiritual seorientation of society.] Islamnews. https://www.islamnews.ru/news-518268.html 
Arnold, R., and L. P. Markowitz. 2018. "The Evolution of Violence within Far-Right Mobilization: Evidence from Russia." Ethnic and Racial Studies 41 (9): 1558-1573.

doi:10.1080/01419870.2017.1332377.

Ashirov, N. 2017. "Otvet muftiya Ashirova uchitelyam Mordovii." [The answer of Ashirov to teaches in Mordovia.] Ansar.ru, January 16. https://golosislama.com/news.php?id=31005

Batyr, R. 2016. “"Muftiyu Moskvy nado prezhde vsego zabotit'sya o svoikh musul'manakh.” [Mufti form Moscow should first of all take care of his own Muslims.] Business-gazeta.ru, December 16. https://www.business-gazeta.ru/article/329146

Benussi, M. 2018. 'Sovereign' Islam and Tatat 'Aqidah': Normative Religious Narratives and Grassroots Criticism Amongst Tatarstan's Muslims.” Contemporary Islam. doi:10.1007/s11562018-0428-8.

Bowen, J. R. 2004. "Does French Islam Have Borders? Dilemmas of Domestication in a Global Religious Field.” American Anthropologist 106 (1): 43-55. doi:10.1525/aa.2004.106.1.43.

Braginskaia, E. 2012. "'Domestication' or Representation? Russia and The Institutionalisation of Islam in Comparative Perspective." Europe-Asia Studies 64 (3): 597-620.

Bustanov, A., and D. Dorodnykh. 2017. "Dzadidizm kak paradigm v izuchenii islama v Rossiiskoi imperii." [Jadidism as a paradigm in the study of Islam in Imperial Russia.] Gosudarstvo, religiya i tserkov' 3: 112-133.

Bustanov, A. K. 2017. "The Language of Moderate Salafism in Eastern Tatarstan.” Islam and Christian-Muslim Relations 28 (2): 183-201. doi:10.1080/09596410.2017.1293372.

Cesari, J. 2012. “Securitization of Islam in Europe.” Die Welt des Islams 52 (83-4): 430-449. doi:10.1163/15700607-201200A8.

Crews, R. 2009. For Prophet and Tsar. Islam and Empire in Russia and Central Asia. Cambridge, MA: Harvard University Press.

Curanovic, A. 2010. "Relations between the Orthodox Church and Islam in the Russian Federation." Journal of Church and State 52 (3): 503-539. doi:10.1093/jcs/csq089.

DeWeese, D. 2016. "It Was a Dark and Stagnant Night ('Til the Jadids Brought the Light): Clichés, Biases, and False Dichotomies in the Intellectual History of Central Asia." Journal of the Economic and Social History of the Orient 59 (1-2). doi:10.1163/15685209-12341393.

di Puppo, L., and J. Schmoller. 2018. "Here or Elsewhere: Sufism and Traditional Islam in Russia's Volga-Ural Region.” Contemporary Islam. doi:10.1007/s11562-018-00434-3.

Dudoignon, S. A. 2015. "Russia." In Oxford Handbook of European Islam, edited by J. Cesari, 517-564. Oxford: Oxford University Press.

Elbasani, A., and J. Tošić. 2017. "Localized Islam(S): Interpreting Agents, Competing Narratives, and Experiences of Faith." Nationalities Papers 45 (4): 499-510.

doi:10.1080/00905992.2017.1300792. 
Fagan, G. 2013. Believing in Russia-Religious Policy after Communism. London: Routledge.

Gainutdin, R. 2015. 'Muftii Ravil' Gainutidn prosit Vladimira Puitna pravo musul'manok nosit' hidzhaby v obrozitel'nykh uchrezhdeniyakh." [Mufti Ravil' Gainutdin asks from Vladimir Putin the right for Muslim women to wear hijab in educational institutions.] Ekho Moskvy, February 4. http://echo.msk.ru/blog/echomsk/1486848-echo/

Gainutdin, R. 2016. “Offitsial'nyi Otvet Shura CMR Muftiyu Chechenskoi Respubliki Mezhievu." [The official answer of the Shura of CMR to the Mufti of Chechen Republic, Mazhiev.] Sovet Muftiev Rossii, October 29. https://muslim.ru/articles/280/16186/

Garaev, D. 2017. "Ideologiya russkoyazychnogo dzhikhadizhma do IGIL: Retsenziya sovetskogo kak rozhdenie ostsovetskogo radikalizma." [The Ideology of Russian-Language Jihadism before ISIS: Reception of the Soviet as the Origin of Post-Soviet Radicalism.] Gosudarstvo, religiua $i$ tserkov'v Rossii i zarubezhom 35 (3): 170-201. doi:10.22394/2073-7203-2017-35-3-170-201.

Gibadullin, R. M. 2018. "K predystorii Bolgarskoi islamskoi akademii: Stolknovenie 'integratsionnogo' i 'natsionalistechkogo' diskursov." [To the Prehistory of the Bulgarian Islamic Academy: the Clash of Integration and Nationalist Discourses.] Islamovedenie 9 (2): 30-44. doi:10.21779/2077-8155-2018-9-2-30-44.

Hashas, M. 2018. The Idea of European Islam: Religion, Ethics, Politics and Perpetual Modernity. London: Routledge.

Kemper, M. 2012. 'Mufti Ravil' Gainutdin: The Translation of Islam into a Language of Patriotism and Humanism." In Islamic Authority and the Russian Language: Studies on Texts from European Russia, the North Caucasus, and West Siberia, edited by A. K. Bustanov and M. Kemper, 105-141. Amsterdam: Uitgeverij Pegasus.

Khakimov, R. 2007. Ternistii Put' K Svobode. [The thorny path to freedom.] Kazan': Tatar.

Khakimov, R. 2013. "Gde nasha Mekka?” Versiya 2.0 [Where is our Mecca? Version 2.0.] Biznes Online, May 11. https://www.business-gazeta.ru/article/79936

Khurmatullin, A. 2010. "Tatarstan: Islam Entwined with Nationalism.” In Russia and Islam. State, Society and Radicalism, edited by R. Dannreuther and L. March, 103-121. London: Routledge.

Laruelle, M., and N. Yudina. 2018. "Islamophobia in Russia. Trends and Societal Context." In Religion and Violence in Russia. Context, Manifestations, and Policy, edited by O. Oliker, 43-63. Washington, DC: Center for Strategic and International Studies.

Laurence, J. 2006. "Managing Transnational Islam: Muslims and the State in Western Europe." In Immigration and the Transformation of Europe, edited by C. Parsons and T. M. Smeeding, 253-275. Cambridge: Cambridge University Press.

Loobuyck, P., J. Debeer, and P. Meier. 2013. "Church-state Regimes and their Impact on the Institutionalization of Islamic Organizations in Western Europe: A Comparative Analysis.” Journal of Muslim Minority Affairs 33 (1): 61-76. 
Muftii SMR pered. ““'s”ezdom” pred'yavili R.Gainutdinu ul'timatum: Ili on, ili D.Mukhetdinov." [Before the meeting a Mufti from CMR sent to R. Gainudin an ultimatum; either he or D. Mukhetdinov.] Islam I Oshchestvo, December 18. http://islamio.ru/news/policy/muftii_smr_ pered_sezdom_predyavili_r_gaynutdinu_ultimatum_ili_oni_ili_d_mukhetdinov/ Mukhetdin, D. 2016. Rossiiskoe musul'manstvo: Traditsii ummy v usloviyakh evraaziiskoi tsivilizatsii. [Russian Muslim community: the traditions of Umma in the circumstances of Eurasian civilization.] Moscow: Medina.

Mukhetdin, D. 2017. "Mukhtasib Mukhetdin o probleme khidzhaba v kontekste svetskoi sisteme obrazovanii." Sankt-Peterburgskii mukhtasibat, January 31. http://islamdumspb.ru/blog/muhta sib-muhetdin-o-probleme-hidzhaba-v-kontekste-svetskoj-sistemy-obrazovaniya

Nielsen, J. 2007. “The Question of Euro-Islam: Restriction or Opportunity?” In Islam in Europe, Diversity, Identity and Influence, edited by A. Al-Azmeh and E. Fokas, 33-48. Cambridge: Cambridge University Press.

Prozorov, S. M. 2004. Islam kak ideologicheskaya sistema. Moskow: RAN.

Pumma. 2015. 'Silant'ev: Deyatel'nost' imamov, kotorye poluchili obrazovanie za rubezhom, nuzhno zapretit'." Golos Islama, December 23. https://golosislama.com/news.php?id=28706

Putin, V. 2013. "Nachalo vstrechi s muftiyami dukhovnykh upravlenii musul'man Rossii." [The beginning of the meeting with muftis of spiritual administrations of Russia.] October 22. http://www.kremlin.ru/events/president/transcripts/19474

Radnitz, S. 2006. "Look Who's Talking! Islamic Discourse in the Chechen Wars." Nationalities Papers 34 (2): 237-256. doi:10.1080/00905990600720328.

Rexhepi, P. 2018. "Arab Others at European Borders: Racializing Religion and Refugees along the Balkan Route." Ethnic and Racial Studies 41: 2215-2234. doi:10.1080/01419870.2017.1415455.

Rogozina, S. 2018. 'Zashchishchaya 'traditsionnyi' islam ot 'radikal'nogo': Diskurs islamofoii v Rossiiskikh SMI." [Defending 'traditional' Islam from 'radical': discourse of Islamophobia in Russian mass media.] Gosudarstvo, religiya i tserkov 2: 272-299.

Roy, O. 2006. Globalized Islam: The Search for a New Ummah. New York: Columbia University Press.

Saeed, A. 2009. "Muslims in the West and Their Attitudes to Full Participation in Western Societies: Some Reflections." In Secularism, Religion and Multicultural Citizenship, edited by G. B. Levey, T. Modood, and C. Taylor, 200-215. Cambridge: Cambridge University Press.

Sakaranaho, T. 2015. "The Governance of Transnational Islam: Introduction.” Journal of Religion in Europe 8 (1): 1-5. doi:10.1163/18748929-00801001.

Sibgatullina, G. 2019. "Translating Islam into the Language of the Russian State and the Orthodox Church." Religion, State \& Society 47: 2.

Sohrabi, H. 2016. "Identity and Muslim Leadership: The Case of Australian Muslim Leaders." Contemporary Islam 10 (1): 1-16. doi:10.1007/s11562-015-0325-3. 
"Sotsial'naya doktrina rossiiskikh musul'man." 2015. [The social doctrine of Russian Muslims.] Sovet Muftiev Rossii, July 1. https://www.muslim.ru/articles/280/13635/

Stoeckl, K. 2016. "The Russian Orthodox Church as Moral Norm Entrepreneur." Religion, State \& Society 44 (2): 132-155. doi:10.1080/09637494.2016.1194010.

Sunier, T. 2014. "Domesticating Islam: Exploring Academic Knowledge Production on Islam and Muslims in European Societies." Ethnic and Racial Studies 37 (6): 1138-1155. doi:10.1080/ 01419870.2012 .753151$.

Tolz, V., and S.-A. Harding. 2015. "“From "Compatriots" to "Aliens": The Changing Coverage of Migration on Russian Television." The Russian Review 74: 452-477. doi:10.1111/russ.12025.

Tuaev, M. 2016. "Bogoslovy obvinili chechenskikh sufiev v popytke vnesti raskol sredi musul'man." [Theologians accused Chechenia Sufis of an attempt to create discord within Muslims.] Kavkazskii Uzel, September 3. http://www.kavkaz-uzel.eu/articles/288674/

Verkhovsky, A. 2018. "The State against Violence in Spheres Related to Religion.” In Religion and Violence in Russia. Context, Manifestations, and Policy, edited by O. Oliker, 11-42. Washington, DC: Center for Strategic and International Studies.

Williams, R. H. 2011. "Creating an American Islam: Thoughts on Religion, Identity, and Place." Sociology of Religion 72 (2): 127-154. doi:10.1093/socrel/srr022.

Yazbeck Haddad, Y., and T. Golson. 2007. "Overhauling Islam: Representation, Construction, and Cooption of "Moderate Islam" in Western Europe." Journal of Church and State 49 (3): 487-515. doi:10.1093/jcs/49.3.487emphasis on adherence to loyalism and political conservatism 